\title{
ЯКІСТЬ ПІДГОТОВКИ ВІЙСЬКОВИХ ФАХІВЦІВ У КОНТЕКСТІ ПОНЯТЬ СИСТЕМНОСТІ ТА ТЕХНОЛОГІЧНОСТІ
}

У статті розглянуто проблему якості підготовки військових фахівиів як основоположну складову функціонування педагогічної системи вищого військового навчального закладу. Обгрунтовано актуальність досліджуваної проблеми, сутність, принциии та структуру якості як системної категорії, технологічний підхід до якості освіти у складі таких складових: проективна, прочесуальна, контрольна, моніторингова, коригувальна. Розглянуто системний підхід до змісту вищої військової освіти як складової процесу проектування підготовки військових фахівців.

Ключові слова: якість освіти; підготовка військових фахівців; система; технологізація; управління; проектування; зміст освіти; коригування.

Постановка проблеми. Необхідність та актуальність дослідження проблеми якості підготовки військових фахівців у сучасних умовах визначається низкою чинників: по-перше, від якості їх підготовки залежить рівень обороноздатності держави, бойової готовності й боєздатності Збройних Сил (ЗС) України; по-друге, якість освіти визначає розвиток військової науки i техніки, озброєння та їх застосування i $\epsilon$ вагомим інвестиційним ресурсом у сектор безпеки та оборони держави; по-третє, якість підготовки офіцерських кадрів сприяє формуванню важливості й престижності військової служби; по-четверте, якість військової освіти сприяє формуванню військової еліти, загальної культури військового середовища й визначає їх позитивний вплив на суспільство та статус військовослужбовців у суспільстві; по-п'яте, якість підготовки фахівців у вищих військових навчальних закладах (ВВН3) набуває все більшого значення в забезпеченні конкурентоспроможності військової освіти нашої держави серед інших країн, де готуються військові професіонали; по-шосте, якість здобутих військовими фахівцями у ВВНЗ компетенцій, знань, умінь, навичок визначає їх спроможність високоефективно виконувати завдання в миротворчих операціях 3 підтримання миру й безпеки, дієво сприяє утвердженню авторитету нашої держави та її ЗС на міжнародній арені; по-сьоме, стійким глобалізаційним падінням якості освіти й відсутністю універсального інструментарію ії оцінки.

Тривалі за часом традиційні підходи до підготовки фахівців, що мали місце в наукових дослідженнях, виходили переважно зі специфічних цілей $\mathrm{i}$ змісту освіти, методологічних та ідеологічних настанов, наявних політичних, військових, технологічних й економічних вимог та умов. При цьому проблема якості освіти декларувалася, але не знаходила дієвої матеріалізації 
внаслідок недостатньої дослідженості питань iï системності й технологічності.

Аналіз досліджень і публікацій. Вимоги щодо підвищення захисту національних інтересів, територіальної цілісності України, боєздатності військ (сил), якості підготовки військових фахівців усіх ступенів освіти, рівнів військового управління, основних стратегічних напрямів розвитку освіти містяться в основоположних нормативно-правових актах (Стратегія національної безпеки України, Воєнна доктрина України, Національна стратегія розвитку освіти в Україні на період до 2021 року).

Проблеми якості освіти, освітньої діяльності знайшли відображення в ряді наукових праць, а саме: сутність категорії якості та іiі вимірювання [3], дидактичні засади підготовки військових фахівців, інноваційна спрямованість військової освіти [6; 12], основні засади контролю якості навчання [5], Деякі наукові видання й публікації, нормативні документи присвячено теоретичним і практичним питанням управління якістю освіти, впливу мотиваційних чинників на неї й діяльність колективів, моніторингу якості підготовки військових фахівців [2; 4; 11].

Метою статті $є$ обгрунтування якості підготовки військових фахівців як системи та технології.

Виклад основного матеріалу. Поняття «якість»-філософська категорія, що «...виражає внутрішню визначеність предмета, яка становить специфіку, що відрізняє його від усіх інших» [1, с. 1423]. Одночасно якість це об'єктивна й достатньо повна характеристика об'єктів, що виявляється в сукупності їх властивостей [9, с. 567].

Як стверджує К.В. Корсак, застосування цього поняття до освіти «порівняно нова справа, викликана самим життям, пошуками як загальноприйнятого його визначення, так і формування засобів вимірювань» [3, с. 121]. Якість, як вважає П. П. Одерій, «...містить комплекс ознак: оволодіння системою знань, навичок i вмінь використовувати їх у професійній діяльності» [5, с. 17]. На думку О. І. Субетто, якість підготовки фахівців - інтегральний показник стану навчання й рівня знань студентів [10, с. 71]. Й. Кондо поняттям «якість» характеризує результат процесу, тобто за його твердженням, «вона відноситься до наслідку у причиннонаслідковій залежності» [2, с. 3].

Як бачимо, існують різні підходи щодо тлумачення поняття «якість підготовки фахівців», що відрізняються один від одного повнотою врахування певних ознак фахівця, рівня його знань, умінь використовувати їх у практичній діяльності, а також складових навчального процесу тощо. Водночас, як слушно відзначає С. М. Ніколаєнко, «система якості передбачає реалізацію функцій планування, управління, забезпечення й поліпшення (оптимізація якості)» [4, с. 17].

Поліпшення якості та підвищення ефективності будь-яких процесів знаходиться у площині їх наукового обгрунтування. Адже, щоб планувати, коригувати, контролювати й стимулювати підвищення якості, необхідно, 
передусім, надійно засвоїти параметри i складові цього процесу за сукупністю властивостей, що їх характеризують. Тому комплексні, системні оцінки якості й ефективності дістають дедалі ширшого застосування.

Узагальнюючи та доповнюючи думки вчених щодо визначення якості освіти як системи, зазначимо, що ï сутність у межах теорії трансформації систем [8] найповніше може бути представлена таким чином: 1) система обов'язково містить у собі сукупність елементів; 2) елементи системи певним чином пов'язані між собою; 3) пов'язані елементи системи створюють своєрідну цілісність; 4) вони знаходяться в постійній взаємодії шляхом обміну енергією; 5) функціонуванню системи притаманні певні закономірності, принципи, суперечності; 6) властивості системи відмінні від властивостей окремих елементів сукупності; 7) система знаходиться під впливом зовнішніх і внутрішніх чинників; 8) залежно від умов, обставин впливу вона може набувати стану розвитку, руйнації, хаосу тощо.

3 позииії викладеного розглянемо якість підготовки військових фахівиів як системну категорію. Для цього використаємо методологію TQM (Total Quality Management) як комплексну систему, орієнтовану на постійне підвищення якості й мінімізацію витрат [3]. Основна філософія TQM базується на основоположному принципі «поліпшенню немає меж» i характеризується спеціальним поняттям - «постійне поліпшення якості» (quality improvement). Зазначимо, що методологія TQM розроблена й здобула визнання в системі загального менеджменту якості у виробничій сфері. Завданням нашого дослідження $є$ iіi адаптація до управлінських аспектів якості підготовки військових фахівців як системної категорії. У межах методології TQM якість підготовки військових фахівців як система має базуватися на таких принципах:

- пріоритету кінцевої мети;

- єдності системи як цілого та як сукупності ії елементів;

- взаємозв'язку і взаємозумовленості складових системи;

- орієнтації на підготовку військових фахівців для ЗС України в повній відповідності зі штатно-посадовими призначеннями;

- оптимальності керівництва підготовкою військових фахівців;

- солідаризації загалу учасників освітнього процесу;

- оптимальності організаційно-методичних засад процесу підготовки військових фахівців і всебічність його забезпечення;

- комплексності здійснення управлінських і мотиваційних процедур;

- спрямованості на постійне покращення освітнього процесу та якості підготовки військових фахівців;

- динамічного розвитку системи, адаптації ï до вимог і потреб особистості;

- прийняття рішень на підставі аналітичних і фактичних даних;

- взаємозв'язку і взаємовпливу безпосередніх та опосередкованих учасників підготовки військових фахівців; 
- урахування потенційних можливостей і суперечностей, зовнішніх та внутрішніх впливів;

- усебічного забезпечення.

Розкриття сутності зазначених принципів не представляється можливим унаслідок обмеженості обсягу статті. Наведемо лише узагальнені структурні складові системи якості підготовки військових фахівців, що корелюються 3 ними:

- місія й мета підготовки військових фахівців;

- мотивація кандидатів, сформована на основі їх особистісних якостей та соціальних гарантій;

- підготовленість кандидатів;

- організаційне й інформаційне забезпечення їх відбору;

- діяльність ВВНЗ із проведення вступних випробувань, організації освітнього процесу та всебічності його забезпечення;.

- стан управління системою підготовки військових фахівців на всіх ієрархічних рівнях;

- нормативне, змістове, науково-методичне, технологічне, фінансове й інформаційне забезпечення;

- рівень підготовленості науково-педагогічних працівників;

- сформованість позитивного морально-психологічного стану в навчальних колективах;

- стан наукової, науково-технічної та інноваційної діяльності;

- відповідність матеріально-технічної бази цілям і завданням підготовки військових фахівців;

- зв'язок із бойовою й повсякденною діяльністю військ (сил);

- наявність ефективної системи мотивації і стимулювання діяльності;

- дієвість контрольних та моніторингових процедур.

Узагальнюючи викладене, зазначимо, що якість підготовки військових фахівців $\epsilon$ інтегральною характеристикою освітнього процесу ВВНЗ, системною категорією, визначається ступенем обгрунтованості й дієздатності таких складових: мети навчання (для чого навчати), управлінських процедур (як управляти навчанням), змісту навчання (чому навчати), методів, засобів та принципів організації процесу навчання (як навчати), а також має відповідати вимогам стандартів ДСТУ ISO 9001-2001, ДСТУ ISO 9004-2001 [11]. Згідно з ДСТУ ISO 9001-2001 до всіх процесів можна застосувати методологію, відому як «Плануй-Виконуй-ПеревіряйДій» («Plan-Do-Check-Act»). Плануй: установлюй цілі та процеси, необхідні для видачі результатів, що відповідають вимогам замовника й політиці організаційної структури. Виконуй: упроваджуй процеси. Перевіряй: контролюй і вимірюй процеси, а також звітуй про результати. Дій: вживай заходи для постійного поліпшення показників функціонування процесу.

Важливим аспектом системного підходу до будь-яких процесів та організаційних структур є функція управління. 
Управління якістю підготовки військових фахівців як системною категорією не набуло цілісного характеру й відбувається переважно на засадах фрагментарності. Основними причинами такого стану є:

- нехтування нормативними та стандартизованими вимогами щодо системного підходу до забезпечення якості освіти;

- низька ефективність координації робіт із забезпечення реалізації державної політики у сфері управління якістю освіти;

- відсутність чіткого цілепокладання 3 орієнтацією на досягнення кінцевого позитивного результату;

- низька обізнаність фахівців відповідних освітянських структур щодо функціонування сучасних систем управління;

- недостатній рівень досліджень із проблем науково-методичного забезпечення якості підготовки фахівців;

- недостатність фінансових i матеріально-технічних ресурсів для всебічного забезпечення якості підготовки фахівців.

Технологічний підхід до якості підготовки військових фахівців як системи може бути представлений такими складовими: проективна, процесуальна, контрольно-моніторингова (оцінка, аналіз), коригувальна [7]. Розглянемо лише проблему системного підходу до змісту військової освіти як частини проективної складової.

Проблема змісту освіти в інших науково-педагогічних і практичних проблемах завжди стояла на першому місці. I це зрозуміло: людству на всіх етапах свого розвитку доводилося вирішувати, чому навчати підростаюче покоління. Провідне положення ця проблема зберігає і в умовах радикальних змін у політичній, соціально-економічній, науково-технічній, військовій, культурній і власне освітньо-педагогічній сферах. Тривалий час в освіті домінували переважно емпіричні підходи щодо формування іiі змісту. Це призводило до нехтування науковими дослідженнями, невизначеності щодо оптимальної сбалансованості загальної структури змісту та його ієрархічних складових, невиправданого зростання об'єму навчального матеріалу, маніпулювання суб' єктивними міркуваннями щодо пріоритетності тих чи тих знань, негативного впливу на якість підготовки фахівців.

Дослідження й висвітлення окремих загальнодидактичних тенденцій змісту освіти в педагогічній літературі не склали цілісної теорії і не стали обгрунтованою науковою основою для вирішення задач практичної педагогіки - навчання, виховання, розвитку й психологічної підготовки фахівців до майбутньої професійної діяльності. Стало вочевидь, що формування змісту освіти потрібно розглядати як цілісну, комплексну проблему на основі теоретико-методологічних підходів, переосмислення зробленого, узагальнення попередніх наукових та експертних досліджень, вирішення ряду практичних питань і проблем.

Останнім часом у системі вищої освіти здійснюється перехід до нового покоління галузевих стандартів вищої освіти на основі компетентнісного підходу, що вважається необхідним етапом на шляху реформування системи 
освіти в Україні. Застосування цього підходу до створення галузевих стандартів вищої освіти, на думку розробників, не замінює традиційну для вітчизняної освіти систему «знання, уміння, навички», а створює передумови для більшого й гнучкішого наближення результатів освіти до потреб і вимог ринку праці, подальшого розвитку освітніх технологій та системи освіти в цілому. Однак запропонована система формування компетенцій на основі змістових модулів, що входять до навчальних дисциплін (практик), мало що змінює у предметній структурі підготовки фахівців із вищою освітою, оскільки освітньо-професійні програми побудовані на предметній основі. При цьому для загальної спрямованості державних галузевих стандартів вищої освіти, зокрема і стандартів вищої військової освіти, продовжують залишатися характерними такі властивості:

- нехтування важливими етапами в розробці стандартів вищої освіти, особливо їх широкою експертизою та експериментальною апробацією;

- високий ступінь формалізації, відсутність дієвих механізмів корекції;

- абстрактність цілепокладання;

- недостатня адаптованість до вимог майбутньої військовопрофесійної діяльності й викликана цим певна ідеалістичність характеру кваліфікаційних вимог (компетенцій);

- переважання дисциплінарної структури навчання над міждисциплінарною, незбалансованість із процесами інтеграції змісту навчання та підсилення міждисциплінарності;

- установка на відносно жорстке регулювання змісту освіти;

- перевантаження змісту вищої освіти;

- спрямованість на одночасне вивчення відносно великої кількості зразків озброєння та військової техніки;

Процесу запровадження державних галузевих стандартів вищої освіти притаманні такі ознаки:

- збереження орієнтації на інформаційно-знаннєву модель підготовки;

- послабленість блоку діяльнісно-компетентнісних результатів навчання;

- недостатня особистісна спрямованість освітнього процесу;

- нестача технологічних, тренажерних i середовищних систем та засобів навчання;

- низький оціночно-діагностичний потенціал, відсутність можливостей (інструментальних, методичних, часових тощо) оцінити реальну якість підготовки фахівців за компетенціями, визначеними кваліфікаційними вимогами та освітньо-професійними програмами;

- слабка представленість базових навичок (компетенцій), що мають надпрофесійний, метапрофесійний, інноваційний характер;

- недостатнє врахування світових тенденцій розвитку вищої школи, особливо вищих навчальних закладів провідних країн світу;

- відсутність дієвого моніторингу дотримання освітніх стандартів, його використання для проектування, організації, контролю та коригування реального освітнього процесу у вищих навчальних закладах. 
Системний і технологічний підхід до змісту військової освіти, на нашу думку, потребує:

- формування й розвитку у майбутніх фахівців професійної свідомості;

- визначення системоутворюючих факторів, що дасть змогу розгорнути зміст освіти в його логічній, психолого-педагогічній системності та спадкоємності. Логічне упорядкування навчального матеріалу має підкорятися логіці організації навчальної діяльності, психолого-педагогічним закономірностям іiі розвитку в системі військово-педагогічного процесу у BBH3;

- розроблення принципів, що мають бути покладені в основу формування та реалізації змісту підготовки військових фахівців (компетентнісної моделі фахівця за спеціальністю);

- пошуку й запровадження інноваційних педагогічних технологій щодо реалізації змісту підготовки військових фахівців.

3 урахуванням викладеного в основу розроблення та реалізації компетентнісної моделі військового фахівця різних рівнів вищої освіти й ланок управління можуть бути покладені такі принципи:

- цілісності, системності (стандартизація, міжпредметна інтеграція, нормативно-правове забезпечення, спрямованість на підготовку військових фахівців за визначеною спеціальністю, кваліфікацією та посадовим призначенням у підрозділах і частинах Збройних Сил України на основі компетентнісного підходу);

- динамічності навчання;

- урахування специфіки підготовки військових фахівців командного й інженерного профілю за освітньо-кваліфікаційними рівнями та ланками управління;

- ієрархічності (ступеневості, здобуття військової освіти за дво- або трицикловою системою підготовки);

- технологізації (проектування, комунікація й організація, контроль, коригування);

- амбівалентності, тобто взаємодоповнюваності та єдності протилежних якостей, можливості аналізу й виявлення характеристик за допомогою різних понять;

- орієнтації нормативних і варіативних частин змісту гуманітарних, соціально-економічних, професійно-орієнтованих та спеціальних навчальних дисциплін на спеціальність (спеціалізацію) і кваліфікацію військового фахівця;

- органічної єдності змісту фундаментально-теоретичної та практичної підготовки військового фахівця;

- діагностичності;

- усебічного матеріально-технічного й фінансового забезпечення;

- відкритості для реальної реалізації та модернізації;

- моніторингу якості підготовки військових фахівців і коригування військово-педагогічного процесу. 
Висновки та перспективи подальших досліджень. Проблему поліпшення якості підготовки військових фахівців розглянуто й досліджено iз застосуванням теорії та методології систем і системного аналізу 3 визначенням принципів, структури, функцій, цілей зазначеної категорії, закладених у її конструкцію.

Урахування системного й технологічного підходу до якості підготовки фахівців має забезпечити інноваційний розвиток військової освіти, іiі динамічний рух, престижність у майбутньому інформаційному суспільстві та вагомий внесок у справу надійного зміцнення обороноздатності держави і іiі збройних сил. Серед перспективних напрямів подальших досліджень відзначимо такі: обгрунтування шляхів і механізмів практичної реалізації принципів системності щодо якості підготовки військових фахівців, запровадження при цьому складових технологічного підходу.

\section{ЛІТЕРАТУРА}

1. Великий тлумачний словник сучасної української мови /Уклад. і гол. ред. В. Т. Бусел. - К. : Ірпінь, ВТФ «Перун», 2001. - 1440 с.

2. Кондо Й. Управление качеством в масштабах компании: становление и этапы развития /Й Кондо. - К. : Издательский дом «АДЕФ-Украина, 2007. - 256 с.

3. Корсак К. В. Якість педагогічних вимірювань: нерозв'язана проблема / К. В. Корсак // Освіта і управління. - 1999. - № 3. - С. 130.

4. Ніколаєнко С. М. Управління якістю вищої освіти: теорія, аналіз і тенденції розвитку: [монографія] / С. М. Ніколаєнко. - К. : Київ. нац. торг.-екон. ун-т, 2007. - 519 с.

5. Одерий Л. П. Основы системы контроля качества обучения: учеб. пособ. / Л. П. Одерий. - К. : ИСИО, 1995. - 32 с.

6. Приходько Ю. І. Теоретико-методологічні основи інноваційної політики у підготовці військових фахівців / Ю.І.Приходько // Збірник тез доповідей Міжнародної науково-технічної конференції «Перспективи розвитку озброєння та військової техгіки Сухопутних військ», 11-12 травня 2017 року, Львів. - Львів : МОУ, НАСВ.- С. 324-325.

7. Приходько Ю. І. Якість освіти як системна категорія / Ю. І. Приходько // Збірник наукових праць «Військова освіта». - К. : МО України. - 2008.-№ 2(22). - С. 13-23.

8. Приходько Ю. І. Теоретико методологічні основи трансформації систем / Ю. І. Приходько // Збірник наукових праць «Військова освіта» Національного універсистету оборони Украни. - 2016. - № 2(34). - С. 184-196.

9. Советский энциклопедический словарь / Науч.-ред. совет: А. М. Прохоров (предс.) и др. - М. : Сов. энциклопедия, 1981. - 1600 с.

10. Субетто А. И. Категория качества и эффективности в теории педагогических систем / А. И. Субетто //Управление качеством подготовки специалистов в высшей школе. - Горький, 1989. - 127 с.

11. Системи управління якістю. Вимоги (ISO 9001:2000, IDT). - Київ : Держстандарт України, 2001. - 23 с.

12. Ягупов В. В. Військова дидактика: навч. посіб. / В. В. Ягупов . - К. : Вид.поліграф. центр «Киӥвський університет», 2000. - 400 с.

\section{REFERENCES}

1. Velykyy tlumachnyy slovnyk suchasnoyi ukrayins'koyi movy (2001) [Great explanatory dictionary of modern Ukrainian language] / Uklad. i hol. red. V.T. Busel. - K.: Irpin', VTF «Perun» (in Ukrainian). 
2. Kondo, Y. (2007). Upravlenye kachestvom v masshtabakh kompanyy: stanovlenye y эtapы razvytyya [Quality management in the company: establishment and development stages] Per. s anhl. - K. : Yzdatel'skyy dom «ADEF-Ukrayna».

3. Korsak, K.V. (1999).Yakist' pedahohichnykh vymiryuvan': nerozv"yazana problema [Quality of pedagogical measurements: unresolved problem]. Osvita i upravlinnya. - № 3. - S. 130 (in Ukrainian).

4. Nikolayenko S. M. (2007). Upravlinnya yakistyu vyshchoyi osvity: teoriya, analiz i tendentsiyi rozvytku: [monohrafiya] [Higher Education Quality Management: Theory, Analysis and Development Trends]. - K. : Kyyiv. nats. torh.-ekon. un-t (in Ukrainian).

5. Oderyy L. P. (1995). Osnovy systemy kontrolya kachestva obuchenyya: [ucheb. posobye] [Fundamentals of quality control system]. - K. : YSYO (in Ukrainian).

6. Prykhod'ko, Yu. I. Teoretyko-metodolohichni osnovy innovatsiynoyi polityky u pidhotovtsi viys'kovykh fakhivtsiv [Theoretical and methodological foundations of innovation policy in the training of military specialists]. Zbirnyk tez dopovidey Mizhnarodnoyi naukovotekhnichnoyi konferentsiyi «Perspektyvy rozvytku ozbroyennya ta viys'kovoyi tekhhiky Sukhoputnykh viys'k», 11-12 travnya 2017 roku, L'viv. - L'viv: MOU, NASV.- S. 324-325 (in Ukrainian).

7. Prykhod'ko, Yu. I. (2008). Yakist' osvity yak systemna katehoriya [Quality of education as a system category]. Zbirnyk naukovykh prats' "Viys'kova. osvita". - K.: MO Ukrayiny. № 2(22). - S. 13-23 (in Ukrainian).

8 Prykhod'ko,Yu.I. (2016). Teoretyko metodolohichni osnovy transformatsiyi system [Theory of methodological foundations of systems transformation]. Zbirnyk naukovykh prats' "Viys'kova osvita" Natsional'noho universystetu oborony Ukrany. - № 2(34). - S. 184-196 (in Ukrainian).

9. Sovetskyy эntsyklopedycheskyy slovar' (1981) [Soviet Encyclopedic Dictionary] / Nauch.-red. sovet: A.M. Prokhorov (preds.) y dr. - M. : Sov. эntsyklopedyya.

10. Subetto, A. Y. (1989). Katehoryya kachestva y эffektyvnosty v teoryy pedahohycheskykh system [Category of quality and effectiveness in the theory of pedagogical systems]. Upravlenye kachestvom podhotovky spetsyalystov v vыsshey shkole. - Hor'kyy.

11. Systemy upravlinnya yakistyu. Vymohy (ISO 9001:2000, IDT) (2001) [Quality management systems. Requirements (ISO 9001: 2000, IDT)]. - Kyyiv : Derzhstandart Ukrayiny (in Ukrainian).

12. Yahupov, V.V. (2000). Viys'kova dydaktyka: [navchal'nyy posibnyk] [Military Didactics]. - K. : Vyd.-polihraf. tsentr "Kyyivs'kyy universytet" (in Ukrainian).

\section{РЕЗЮМЕ}

Юрий Приходько,

кандидат педагогических наук, доцент Национальный университет обороны Украины имени Ивана Черняховского

\section{Качество подготовки военных специалистов в контексте понятий системности и технологичности}

В статье рассмотрено проблему качества подготовки военных специалистов как основополагающей составляющей функиионирования педагогической системы высшего военного учебного заведения. Обосновано актуальность исследуемой проблемь, сущность, принциипы и структуру качества как системной категории, технологический подход $\kappa$ качеству образования в составе таких структурных составляющих: проективная, прочессуальная, контрольная, мониторинговая, корректирующая. Рассмотрено системный подход к содержанию высшего военного образования как составляющей процесса проектирования подготовки военных специалистов. 
Ключевые слова: качество образования; подготовка военных спечиалистов; система; технологизаиия; управление; проектирование; содержание образования; корректирование.

\section{SUMMARY}

Yurii Prykhodko,

Candidate of Pedagogic Sciences, Associate Professor National Defence University of Ukraine named after Ivan Cherniakhovskyi

\section{The quality of training of military specialists in the context of the concepts of systemicity and technology}

Introduction. The necessity and relevance of the study of military specialists' training quality in modern conditions is determined, first of all, by the need to ensure a high level of defense capability, combat readiness and combat capability of the Armed Forces of Ukraine. The problem of the quality of education is often declared and does not find effective materialization as a result of inadequate study of its systemic, technological, and security issues.

Purpose. The purpose of the study is to substantiate the quality of military specialists' training as a system and technological category of military education.

Methods. For the purpose of the research the system of general scientific and special methods of theoretical (analysis of scientific publication on the problem, systematization and generalization, content analysis, systemic, technological approach) and empirical research (control of the educational process, use of diagnostic tools) was used.

Results. The quality of education as a system must meet the requirements of the Public Standards DSTU ISO 9001-2001: "Plan-Do-Check-Act". The main tools and mechanisms of scientific management of military specialists' training quality have been substantiated. The technological approach to the quality of military specialists' training as a system with the following components is developed: projective; procedural; control and monitoring; corrective. The problem of a systematic approach to the content of military education is revealed. The principles, which can be used as the basis for the development and implementation of the competent model of the military specialist, are grounded.

Originality. For the first time, the concept of the quality of education as a system and technology in the context of the author's theory of system transformation has been defined. The consideration of the system and technological approach to the quality of specialists' training should ensure the innovative development of military education.

Conclusion. Perspective directions of further researches: substantiation of ways and mechanisms of practical realization of system and technological approach to the quality of military experts' training.

Key words: quality of education; military specialists' training; system; technology; management; design; content of education; adjustment. 